\title{
Fulminant Hepatic Failure in Measles in a 6-Month-Old Child
}

\author{
Sunil Kumar Sati ${ }^{a}$, , Shreshtha Banga ${ }^{a}$, Swadesh Singh Bhadouria ${ }^{a}$
}

\begin{abstract}
Measles is known to cause self-limiting illness, mostly in children. Measles is a systemic infection with known complications but information regarding the consequences of liver involvement is limited. Fulminant hepatic failure has been reported rarely in very young children. We present here a case of fulminant hepatitis in a 6-month-old child with measles from central India.
\end{abstract}

Keywords: Measles; Hepatitis; Fulminant hepatic failure

\section{Introduction}

Measles is a known childhood self-limiting viral illness, whose control through vaccination has been a major endeavor for decades. Although much success in controlling the spread of measles has been achieved, it still occurs in both developed and developing parts of the world. Measles virus affects various organ systems and there is little information regarding the consequences of liver involvement in measles. We report a case of an infant with measles who developed fulminant hepatic failure.

\section{Case Report}

A 6-month-old previously healthy female infant was seen in the clinic with a history of 3 days of fever, cold symptoms, conjunctival congestion and dry cough. The child developed a maculopapular rash on day 5 that began on her face and then spread to her entire body. She was clinically diagnosed with measles and treated symptomatically with acetaminophen and vitamin A. She was brought to the emergency room after 2 days of lethargy, vomiting and decreased oral intake. There was no history of any hepatotoxic drug ingestion. Emergency room evaluation showed dehydration and icteric sclerae, tender liver $4 \mathrm{~cm}$ below costal margin with a hemoglobin level $11.4 \mathrm{~g} / \mathrm{dL}$,

Manuscript submitted February 8, 2018, accepted February 20, 2018

aPrayaas Children Hospital, Gwalior, Madhya Pradesh, India

${ }^{b}$ Corresponding Author: Prayaas Children Hospital, City Center, Gandhi Road, Gwalior, Madhya Pradesh, 474001, India. Email: Sunilsati84@gmail.com

doi: https://doi.org/10.14740/ijcp294w white blood count $11,100 / \mathrm{mm}^{3}$ (66\% polymorphs, $28 \%$ lymphocytes), serum bilirubin $1.7 \mathrm{mg} / \mathrm{dL}$, direct bilirubin $0.91 \mathrm{mg} /$ $\mathrm{dL}$, aspartate transaminase 7,980 units/L, alanine transaminase 5,120 units/L, blood urea $44 \mathrm{mg} / \mathrm{dL}$, serum creatinine $0.54 \mathrm{mg} /$ $\mathrm{dL}$, prothrombin time $46 \mathrm{~s}$ with INR 3.8.

She was admitted to the pediatric ward with a diagnosis of acute liver failure and started on intravenous fluids, vitamin $\mathrm{K}$ and other supportive treatment including fresh frozen plasma and $\mathrm{N}$-acetyl cysteine. The workup for cause of liver failure revealed negative results for hepatitis $\mathrm{A}, \mathrm{B}$ and $\mathrm{E}$ screen as well as negative Epstein-Barr and cytomegalovirus. Her measles antibodies were positive with IgM levels of 37.42 units/ $\mathrm{mL}$ (lab reference of $<8$ ) and negative $\mathrm{IgG}$ of 4.33 units $/ \mathrm{mL}$ (lab reference of $<8$ ). The ultrasound of the abdomen showed hepatomegaly.

The baby improved on supportive treatment and did not require referral for liver transplantation. At the time of discharge alanine transaminase was $480 \mathrm{U} / \mathrm{L}$, aspartate transaminase was $1,410 \mathrm{U} / \mathrm{L}$, prothrombin time was $15 \mathrm{~s}$ with INR of 1.3 and returned to $<45$ units/L on follow-up. The child is being followed up on a regular basis and is doing well.

\section{Discussion}

Acute hepatitis associated with measles infection is rare in children compared to adults [1]. The prevalence of hepatitis in adults with measles ranges from $71 \%$ to $89 \%[2,3]$ and transaminase levels usually rise to 5 - 10 times the normal level, with jaundice being unusual. In 2001, 189 children with measles were studied during a measles epidemic in Greece, for the prevalence of hepatitis [4]. Only nine children (4.8\%) were found to have increased liver enzymes. One child, who was previously taking anti-epileptic therapy, developed hepatic coma from which he recovered in a month. The severity of hepatitis in measles increases with concurrent use of hepatotoxic drugs, although no such case was observed in our patient.

A literature review revealed very few cases of fulminant hepatic failure due to measles infection [4, 5]. In 2007, Nobili et al reported a case of fulminant hepatitis in an 18-month-old child who required liver transplantation [6]. These authors also demonstrated measles virus in the hepatocytes with electron microscopy and immunohistochemical analysis.

\section{Funding}

None. 


\section{Conflict of Interest}

None.

\section{References}

1. Lee KY, Lee HS, Hur JK, Kang JH, Lee BC. Clinical features of measles according to age in a measles epidemic. Scand J Infect Dis. 2005;37(6-7):471-475.

2. Giladi M, Schulman A, Kedem R, Danon YL. Measles in adults: a prospective study of 291 consecutive cases. $\mathrm{Br}$ Med J (Clin Res Ed). 1987;295(6609):1314.

3. Biron C, Beaudoux O, Ponge A, Briend-Godet V, Corne
F, Tripodi D, Hazart I, et al. [Measles in the Nantes Teaching Hospital during the 2008-2009 epidemic]. Med Mal Infect. 2011;41(8):415-423.

4. Papadopoulou A, Theodoridou M, Syriopoulou V, Mostrou G, Kattamis $\mathrm{CH}$. Hepatitis in children hospitalized with measles: the experience acquired after a Greek epidemic. J Paediatr Child Health. 2001;37(1):55-57.

5. Hashimoto K, Kashihara T, Kotani K, Fujimori E, Ohki A, Kawakami F, Tako H, et al. [A case of measles associated with severe damage of the liver and kidneys]. Nihon Shokakibyo Gakkai Zasshi. 1992;89(2):548-551.

6. Nobili V, Pietro S, Stefania P. Fulminant hepatic failure following measles. Pediatr Infect Dis J. 2007;26(8):766767. 